\section{A possible cause of glandular hypospadias in man}

The incidence of hypospadias in the newborn male is low, being 3.3/1000 (British Medical Journal, 1972). The known causes of hypospadias are progestogen therapy given to the mother in early pregnancy and chromosome abnormalities in the neonate (Aarskog, 1970), but these account for only a small percentage of cases.

There is evidence from animal experiments that impaired or absent fetal testicular function affects the differentiation of the male external genitalia (Jost, 1953), while specific anti-androgen therapy can actually produce hypospadias in male rats (Neumann, Elger, and Steinbeck, 1969; Goldman et al., 1972).

Plasma testosterone concentrations in human male and female fetuses of 12 to 18 weeks' gestation have been measured, and in the male fetuses the development of the urethra has been observed, thus allowing a correlation of the levels of plasma testosterone with the position of the urethral orifice.

\section{Materials and methods}

Umbilical cord blood was collected from male and female fetuses at 12 to 22 weeks' gestation, delivered at hysterotomy, by dividing the cord and allowing blood to drain from both ends. Care was taken to avoid contamination with maternal blood or amniotic fluid. Plasma testosterone was measured by a radioimmunoassay method (Abramovich and Rowe, 1973) that showed minimal cross-reaction with those $\mathrm{C}_{18}, \mathrm{C}_{19}$, and $\mathrm{C}_{21}$ steroids known to be present in human umbilical plasma.

The sex of the fetus was determined and the position of the urethral orifice in the male fetuses was examined using a hand lens or dissecting microscope where necessary.

\section{Results}

The amounts of plasma testosterone in male fetuses are shown in Table I and those from female fetuses in Table II. There are significant differences $(P<0.001)$ between the mean levels in male and female fetuses of the ages 12 to 18 weeks. When the mean values of plasma testosterone in male fetuses are examined, they appear to stay high from 12 weeks to 18 weeks (crown-rump length 7-13 $\mathrm{cm}$ ), but closer examination of the plasma levels in the youngest fetuses suggests that the plasma testosterone climbs from low levels in the youngest fetuses to reach peak levels which persist till about 18 weeks' gestation.

In the two youngest fetuses examined (gestational age 12 weeks, crown-rump length $7 \mathrm{~cm}$, weight 19.5 $\mathrm{g}$ and $21.5 \mathrm{~g}$ ), the testosterone concentrations were $84 \mathrm{ng} / 100 \mathrm{ml}$ and $142 \mathrm{ng} / 100 \mathrm{ml}$, respectively, values lower than the mean levels found in the older fetuses.

TABLE I

Concentration of testosterone in umbilical cord plasma in male fetuses in mid-pregnancy

\begin{tabular}{|c|c|c|c|c|c|}
\hline $\begin{array}{l}\text { Gestational } \\
\text { age (wk) }\end{array}$ & Fetal weight (g) & $\begin{array}{l}\text { Crown-rump } \\
\text { length }(\mathrm{cm})\end{array}$ & No. of fetuses & $\begin{array}{c}\text { Mean testosterone } \\
\text { concentration } \pm S D \\
(\mathrm{ng} / 100 \mathrm{ml})\end{array}$ & $\begin{array}{l}\text { Range of testosterone } \\
\text { concentration } \\
(\mathrm{ng} / 100 \mathrm{ml})\end{array}$ \\
\hline $\begin{array}{l}12-13 \\
13-15 \\
15-18\end{array}$ & $\begin{array}{c}19 \cdot 5-29 \cdot 5 \\
33 \cdot 5-67 \cdot 5 \\
68-146\end{array}$ & $\begin{array}{c}7-8 \\
8 \cdot 1-10 \\
10 \cdot 1-13\end{array}$ & $\begin{array}{r}8 \\
10 \\
6\end{array}$ & $\begin{array}{l}255 \pm 99 \\
235 \cdot 5 \pm 99 \\
265 \pm 90\end{array}$ & $\begin{array}{r}84-379 \\
101-415 \\
184-378\end{array}$ \\
\hline
\end{tabular}

TABLE II

Concentration of testosterone in umbilical cord plasma in female fetuses in mid-pregnancy

\begin{tabular}{|c|c|c|c|c|c|}
\hline $\begin{array}{l}\text { Gestational } \\
\text { age (wk) }\end{array}$ & Fetal weight (g) & $\begin{array}{l}\text { Crown-rump } \\
\text { length }(\mathrm{cm})\end{array}$ & No. of fetuses & $\begin{array}{c}\text { Mean testosterone } \\
\text { concentration } \pm \mathrm{SD} \\
(\mathrm{ng} / 100 \mathrm{ml})\end{array}$ & $\begin{array}{l}\text { Range of testosterone } \\
\text { concentration } \\
(\mathrm{ng} / 100 \mathrm{ml})\end{array}$ \\
\hline
\end{tabular}


When the external genitalia of these two fetuses were examined, the urethral orifice was still on the under-surface of the penis, while in fetuses of crown-rump length of $8 \mathrm{~cm}$ it had approached the tip of the glans. The mean plasma testosterone concentration of the 6 fetuses with crown-rump length of $8 \mathrm{~cm}$ was $302 \mathrm{ng} / 100 \mathrm{ml}$, range 252-379 $\mathrm{ng} / 100 \mathrm{ml}$. In fetuses of crown-rump length of 10 $\mathrm{cm}$ or longer, the urethral orifice appeared to be in the normal adult position. These results confirmed those of Glenister (1954).

\section{Discussion}

When the fetal plasma testosterone levels and the position of the urinary meatus are correlated it can be suggested that the transposition of the orifice to the tip of the penis is associated with rising levels of testosterone. On a fetus of 8 to $10 \mathrm{~cm}$ in crownrump length when there is a reactive proliferation at the anterior extremity of the urethral plate (Glenister, 1954), the levels of testosterone are high and steady and drop well after the completion of the male external genitalia.

These findings do not prove that the positioning of the urinary meatus is dependent on fetal androgen levels in the human, as the high testosterone concentration and the transposition of the meatus may just be a coincidence in timing, but evidence from animal experiments using both anti-androgens and antiserum against testosterone suggests more than a close association.

Neumann et al. (1969), using the androgen antagonist cyproterone acetate in dog fetuses, found that the first sign of an androgen deficiency was the presence of hypospadias, while Goldman et al. (1972), who injected antiserum to testosterone into pregnant rats from 13 to 20 days of gestation, found that the male offspring had hypospadias. Thus it can be suggested in man that because high levels of testosterone are present in the fetus at the time of urethral formation, some cases of glandular hypospadias are caused by an androgen deficit. It is realized that this hypothesis may only apply to a small number of cases as a cause of hypospadias. It may well be that there is a lack of tissue response to normal levels of testosterone. Nevertheless, in the human this correlation of the high and rising androgen levels with the development of the urethra is reinforced by the available animal evidence.

\section{Summary}

Animal experiments strongly point to testosterone being implicated in the differentiation of the fetal male external genitalia. Plasma testosterone levels in human male fetuses are significantly higher than those found in female fetuses just at the time of urethral formation in the male fetuses, suggesting that testosterone in the human may be implicated in the differentiation of the male external genitalia and that its lack may be important in some cases of glandular hypospadias.

I am indebted to Dr. J. McKenzie, Department of Developmental Biology, for his help in examining the male fetuses. I also thank Miss P. Buchan for technical assistance.

\section{REFERENCES}

Aarskog, P. (1970). Clinical and cytogenetic studies in hypospadias. Acta Paediatrica Scandinavica, 59, Suppl. 203.

Abramovich, D. R., and Rowe, P. (1973). Foetal plasma testosterone levels at mid-pregnancy and at term. fournal of Endocrinology, 56, 621 .

British Medical fournal (1972). Leader. Genetics of hypospadias, 4, 189.

Glenister, T. W. (1954). The origin and fate of the urethral plate in man. Fournal of Anatomy, 88, 413.

Goldman, A. S., Baker, M. K., Chen, J. C., and Wieland, R. G. (1972). Blockade of masculine differentiation in male rat fetuses by maternal injection of antibodies to testosterone-3bovine serum albumin. Endocrinology, 80, 716.

Jost, A. (1953). Problems of fetal endocrinology. Recent Progress in Hormone Research, 8, 379.

Neumann, F., Elger, W., and Steinbeck, H. (1969). Drug-induced intersexuality in mammals. Fournal of Reproduction and Fertility, Suppl. 7, 9.

D. R. ABRAMovich

Department of Obstetrics and Gynaecology, University of Aberdeen, Foresterhill, Aberdeen AB9 2ZD.

\section{Iodide sialadenitis in childhood}

Intravenous pyelography is frequently used in the investigation of renal disease in childhood. This is generally a safe procedure, though anaphylactic reactions may follow the intravenous injection of iodide (Tucker and Di Bagno, 1956). A rare occurrence, however, is painful swelling of submandibular or parotid glands known as iodide sialadenitis. This has been reported previously in adults but not hitherto in children (Nakadar and Harris-Jones, 1971; Sussman and Miller, 1956).

\section{Case report}

An 8-year old girl presented with a 6-month history of intermittent right loin pain, dysuria, pyrexia, and vomiting. She was noted to be pale but examination was otherwise negative. Routine analysis of her urine showed no abnormality and culture was sterile. In view of her history she was admitted for further investigations. These showed $\mathrm{Hb} 12.9 \mathrm{~g} / 100 \mathrm{ml}$, WBC $9200 / \mathrm{mm}^{3}$, erythrocyte sedimentation rate $15 \mathrm{~mm} / 1 \mathrm{st}$ hour, urea 28 $\mathrm{mg} / 100 \mathrm{ml}$, creatinine $0.6 \mathrm{mg} / 100 \mathrm{ml}$, uric acid $4.2 \mathrm{mg} /$ $100 \mathrm{ml}$. Serum electrolytes and plasma proteins were normal and her urine remained sterile. 